Acta vet. scand. $1984,25,213-228$.

From the Department of Physiology,

Norwegian College of Veterinary Medicine, Oslo, Norway.

\title{
CALCIUM EFFECTS ON RENAL CONSERVATION OF MAGNESIUM IN COWS
}

By

Karl Halse

HALSE, K.: Calcium effects on renal conservation of magnesium in cows. Acta vet. scand. 1984, 25, 213-228. - Urinary excretion rates for $\mathrm{Ca}, \mathrm{Mg}$ and $\mathrm{P}$ were compared to simultaneous measurements of the same elements in blood plasma of cows recovering from moderate hypocalcaemia post partum and in 1 animal during recovery from hypocalcaemia induced by fasting.

The renal conservation of $\mathrm{Mg}$ was found to be increased during the hypocalcaemia, theoretical tubular reabsorption rates being correlated to plasma Ca with $\mathrm{r}=-0.7, \mathrm{P}<0.001$. The relationship was observed in the plasma Ca range from about 2.0 to $2.6 \mathrm{mmol} / \mathrm{l}$.

The findings may explain the occurrence of hypermagnesaemia in hypocalcaemic cows and the delay in the development of hypomagnesaemia seen in cows with fasting-induced hypocalcaemia.

parturition; fasting; hypocalcaemia; improved renal conservation; hypermagnesaemia; Ca-Mg interrelation; phosphaturia.

Measurements both by Sjollema (1933) and by Jonsgård (1972) show that about $40 \%$ of cows with milk fever have plasma $\mathrm{Mg}$ concentrations well above $1 \mathrm{mmol} / \mathrm{l}$. Occasional values as high as around $1.5 \mathrm{mmol} / \mathrm{l}$ at the time of treatment for the disease were recovered by both authors. The indication would be that the regulation of blood $\mathrm{Mg}$ is influenced by variations in calcium metabolism. This belief is strengthened by the demonstration by Marr et al. (1955) of an abrupt decrease in serum $\mathrm{Mg}$ from hypermagnesaemic levels during successful Ca treatment of cows with milk fever.

Plasma Mg can be high also in the absence of milk fever symptoms in cows which are moderately hypocalcaemic post partum (Dishington 1975). Paradoxically, elevated $\mathrm{Mg}$ levels are 
seen occasionally even in cows made hypocalcaemic by fasting (Halse 1961).

The apparent inverse relationship between plasma $\mathrm{Ca}$ and $\mathrm{Mg}$ indicated by the references above could be due to Ca-dependent variations in renal handling of $\mathrm{Mg}$. The importance of kidney function in determining the plasma $\mathrm{Mg}$ level becomes self-evident when account is taken of the fact that normally the total extracellular $\mathrm{Mg}$ is filtered through the glomeruli several times a day. Even moderate variations in glomerular filtration rate or tubular reabsorption rate must influence the blood $\mathrm{Mg}$ level at which a steady state condition is attained.

Actually, a renal mechanism which could account for inversely related variations in plasma $\mathrm{Ca}$ and $\mathrm{Mg}$ was proposed by Barker et al. (1959) and by Samiy et al. (1960), i. e. competition between the 2 elements for tubular reabsorption. The hypothesis of absorptive pathways common to the 2 elements both in the intestinal wall and in renal tubules was advanced by Alcock \& MacIntyre (1962). In sheep Care \& van't Klooster (1965) found that $\mathrm{Ca}$ and $\mathrm{Mg}$ interferred with the absorption of one another from the ileum, indicating facilitated diffusion by means of a limiting common carrier system.

The hypothetical common carrier system has not yet been identified. Reference is made to reviews of $\mathrm{Mg}$ metabolism by Nordin (1976) and by Ebel \& Günther (1980) and to the review of renal handling of $\mathrm{Mg}$ by Dirks \& Quamme (1978). The renal antagonism between $\mathrm{Ca}$ and $\mathrm{Mg}$ has been confirmed. In recently parathyroidectomized rats (Quamme 1982) infusion of Ca resulted in an increase in the urinary excretion of $\mathrm{Mg}$. In the same animals it was shown by microperfusion of segments of single renal tubuli that the reabsorption of $\mathrm{Mg}$ was reduced, mainly in the loop of Henle, by increasing the concentration of $\mathrm{Ca}$ in the perfusion fluid.

\section{MATERIALS AND METHODS}

The cows used were of the Norwegian Red breed, of varying age, considered to be in good health at the time of observation. Measurements were made on 6 indoor-fed animals during 7 normal, uncomplicated parturitions. Feed rations consisted of hay, grass silage, Beckman-treated straw, roots and concentrates. Cow No. 1 which was observed during 2 successive parturitions 13 
months apart, was also used for a $48 \mathrm{~h}$ fasting experiment during the intervening lactation period, 3 months post partum. Before being fasted she was fed some concentrates and $40 \mathrm{~kg}$ of fresh grass per day.

Signs of paresis were not observed during or after the fast. When re-feeding was initiated the cow was normally alert. The rectal temperature was normal, $39^{\circ} \mathrm{C}$, but the body surface felt cool. Rumen motility was reduced and the appetite was low. However, after 5 days she was back at a daily consumption of $40 \mathrm{~kg}$ of grass and $7 \mathrm{~kg}$ of concentrates. No change in food consumption was noted in connection with a transient decrease in plasma Ca after 10 days of re-feeding.

Urine was collected quantitatively in plastic bags by means of Folley catheters kept permanently inserted into the bladder for up to a fortnight. The total period of urine collection from the date of calving varied in length between 8 days and a fortnight according to the tolerance of the animals to the catheter.

The length of the urine collection intervals varied between 6 and $24 \mathrm{~h}$, short intervals being preferred on the first days post partum while mineral levels were changing rapidly. Varying numbers of urines were obtained before calving, and 1 animal was not sampled at this stage.

Heparinized blood for the determination of plasma minerals was drawn from the jugular vein at the beginning and end of each urine collection interval, and the mean of analyses of the 2 samples were used in the comparison of blood and urine composition.

Urine aliquots were preserved with $\mathrm{HCl}$ and stored together with blood plasma at $+5^{\circ} \mathrm{C}$ until analyses could be performed, within a week's time.

For the determination of $\mathrm{Ca}$ and $\mathrm{Mg}$ the urines were evaporated and dry-ashed in platinum vessels. Urinary phosphorus was measured after wet-ashing with $\mathrm{H}_{2} \mathrm{SO}_{4}$ and $\mathrm{HNO}_{3}$ in microKjeldahl flasks. Ca was measured complexometrically with EGTA by means of a microadaptation of the principle described by Ringbom (1963) using $\mathrm{Zn}^{++}$and Zincon for the end-point detection. $\mathrm{Mg}$ was found by difference after titration of $\mathrm{Ca}+\mathrm{Mg}$ with EDTA in ethanolamin buffer with Eriochrome black T as indicator. Both titrations were performed with an EEL titrator (Evans Electroselenium) Phosphate was measured photometrically by conventional molybdate methods. 

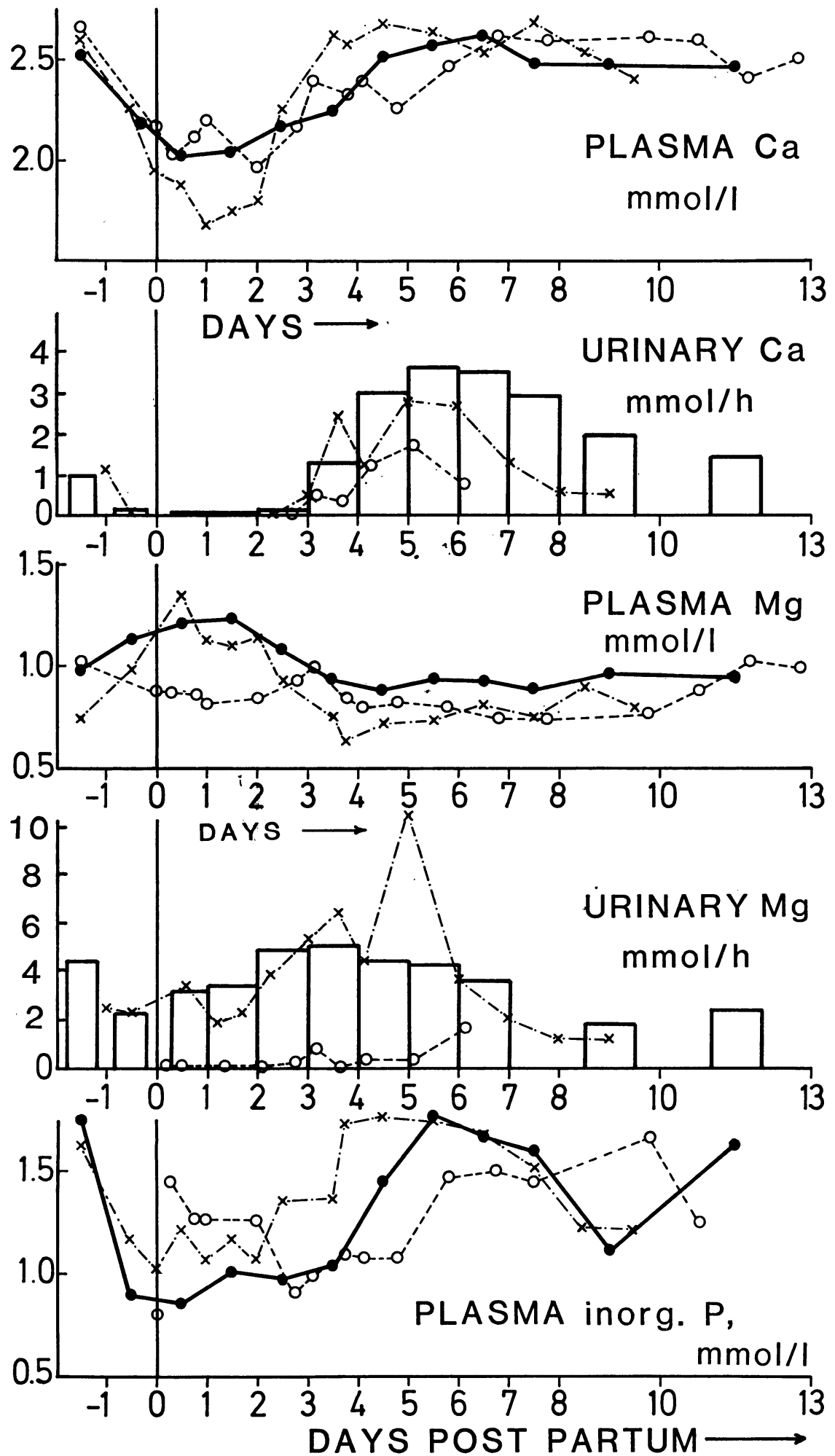


\section{RESULTS}

\section{Calcium and magnesium}

The following points are illustrated in Fig. 1: 1. Plasma Mg was increased during postparturient hypocalcaemia in 6 out of 7 parturitions. 2. One cow which marked herself out by developing phosphaturia (Fig. 2) still showed the inverse relationship between $\mathrm{Ca}$ and $\mathrm{Mg}$ in blood plasma. 3. The single animal failing to show a Ca-related increase in plasma $\mathrm{Mg}$ excreted exceptionally low amounts of $\mathrm{Mg}$ with the urine. 4. Ca effects on renal conservation of $\mathrm{Mg}$ are indicated by the fact that plasma $\mathrm{Mg}$ and renal $\mathrm{Mg}$ excretion rate tended to vary inversely during recovery from hypocalcaemia.

The last-mentioned point is further illustrated by the observations from individual cows in Fig. 3. Within all animals the ratio between $\mathrm{Mg}$ excretion and plasma $\mathrm{Mg}$ was lower at the time of Ca-minimum than after recovery, when plasma Ca culminated.

Additional evidence of Ca-effects on $\mathrm{Mg}$ metabolism was obtained in the fasting experiment (Tables 1 and 2). When the animal became hypocalcaemic, $\mathrm{Mg}$ disappeared from the urine simultaneously with $\mathrm{Ca}$ while plasma $\mathrm{Mg}$ was still at or slightly above the initial level.

The second drop in plasma Ca, 10 days after termination of the fast (Table 2), could be due to a regulatory backlash after a period of overstimulation of mineral mobilizing mechanisms. The important point in the present context is the fact that the spontaneous hypocalcaemia, occurring while dietary $\mathrm{Mg}$ was available, was accompanied by a $50 \%$ increment in plasma $\mathrm{Mg}$. To the retention of extracellular $\mathrm{Mg}$ which must have taken place corresponds a decrease in urinary $\mathrm{Mg}$ during the preceding collection interval.

A renal calcium treshold at $2.3 \mathrm{mmol} / \mathrm{l}$ is indicated in Table 3 . In the averages are included all observations after calving from the 7 parturient cows in Fig. 1.

Fig u re 1. Concentrations in plasma and urinary excretion rates of $\mathrm{Ca}$ and $\mathrm{Mg}$. Inorganic $\mathrm{P}$ in plasma. Variations with time post partum. Fully drawn curves and columns give means from 5 or 4 (inorg. P) parturitions. Separate curves: (O) calving no. 1, low urinary $\mathrm{Mg}$; $(X)$ calving no. 4, phosphaturia (See Fig. 2). 


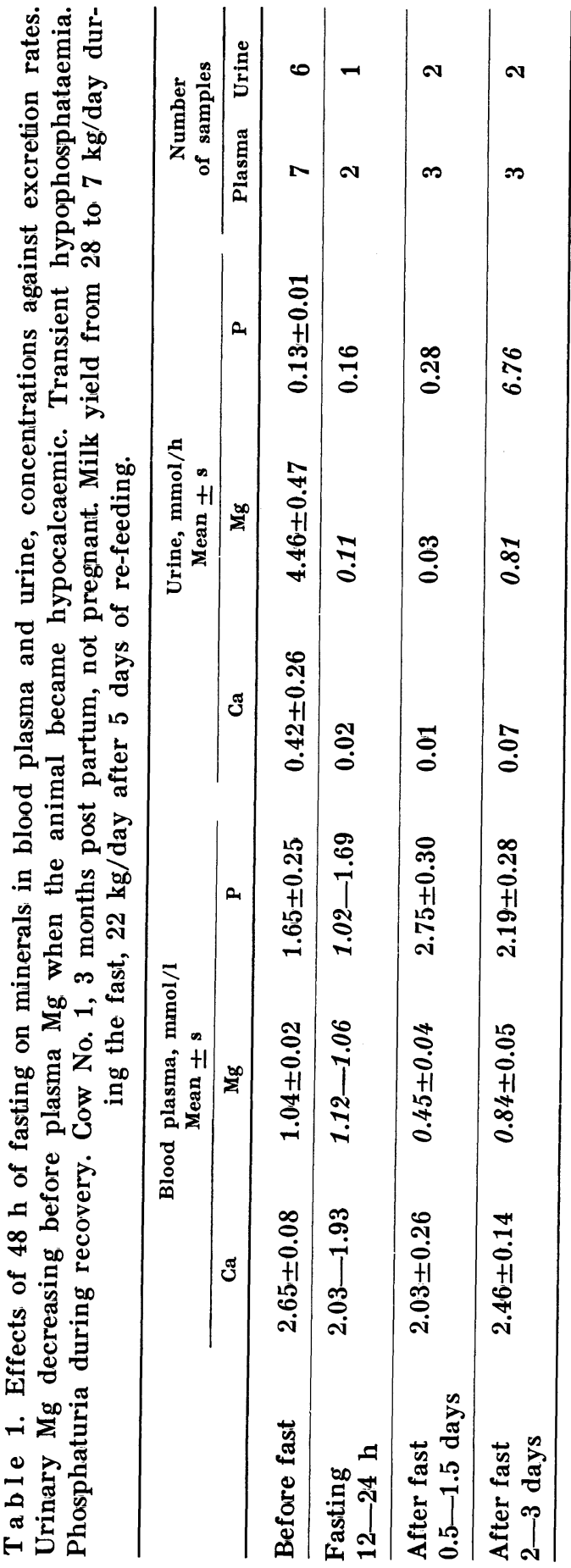



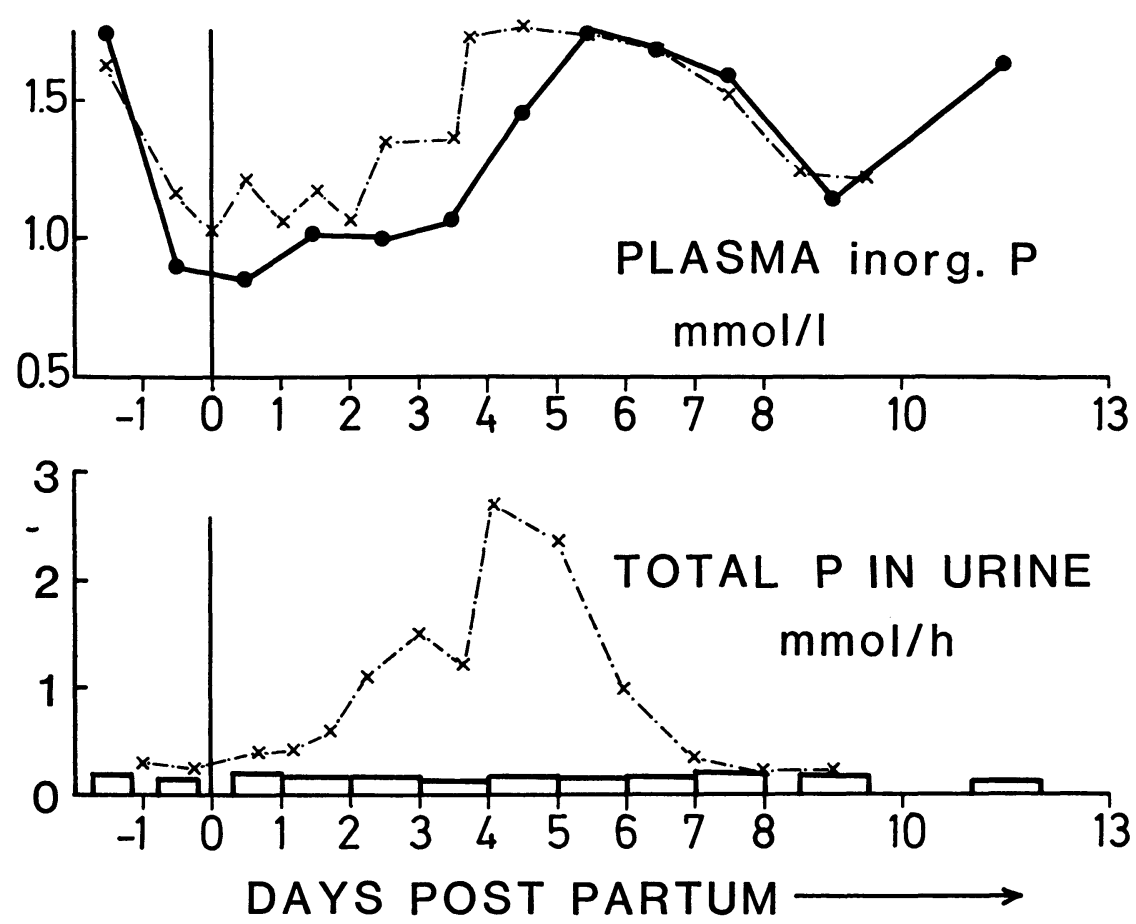

F i g u r e 2. Total $P$ in urine, mmol/h against time post partum, compared to plasma inorganic $P$. Fully drawn curve and columns: 4 parturitions. Separate curves $(x)$ : calving no. 4 with phosphaturia.

T a b l e 2. Spontaneous hypocalcaemia in cow No 1 on the 10 th day of feeding after a two-days' fast (Table 1). Mineral concentrations in plasma and urinary excretion rates. Decreased $\mathrm{Mg}$ excretion and hypermagnesaemia. Hypophosphataemia followed by phosphaturia. Plasma values at the beginning and end of four $24 \mathrm{~h}$ urine collection intervals.

\begin{tabular}{|c|c|c|c|c|c|c|c|}
\hline \multirow{2}{*}{$\begin{array}{l}\text { Days of } \\
\text { feeding }\end{array}$} & \multicolumn{3}{|c|}{ Blood plasma, mmol/1 } & \multicolumn{3}{|c|}{ Urine, $\mathrm{mmol} / \mathrm{h}$} & \multirow{2}{*}{$\begin{array}{l}\text { Milk } \\
\text { kg/d }\end{array}$} \\
\hline & $\mathbf{C a}$ & $\mathbf{M g}$ & $\mathbf{P}$ & $\mathbf{C a}$ & $\mathbf{M g}$ & $\mathbf{P}$ & \\
\hline \multirow[t]{2}{*}{8} & 2.99 & 0.94 & 1.21 & & & & 21.1 \\
\hline & & & & 0.71 & 8.36 & 0.26 & \\
\hline \multirow[t]{2}{*}{9} & 2.75 & 0.96 & 1.32 & & & & 20.6 \\
\hline & & & & 0.67 & 5.73 & 0.24 & \\
\hline \multirow[t]{2}{*}{10} & 1.83 & 1.56 & 0.61 & & & & 19.2 \\
\hline & & & & 0.06 & 9.6 & 0.29 & \\
\hline \multirow[t]{2}{*}{11} & 2.51 & 1.13 & 1.95 & & & & 22.5 \\
\hline & & & & 0.92 & 4.8 & 2.9 & \\
\hline 12 & 2.70 & 0.92 & 2.27 & & & & 23.3 \\
\hline
\end{tabular}




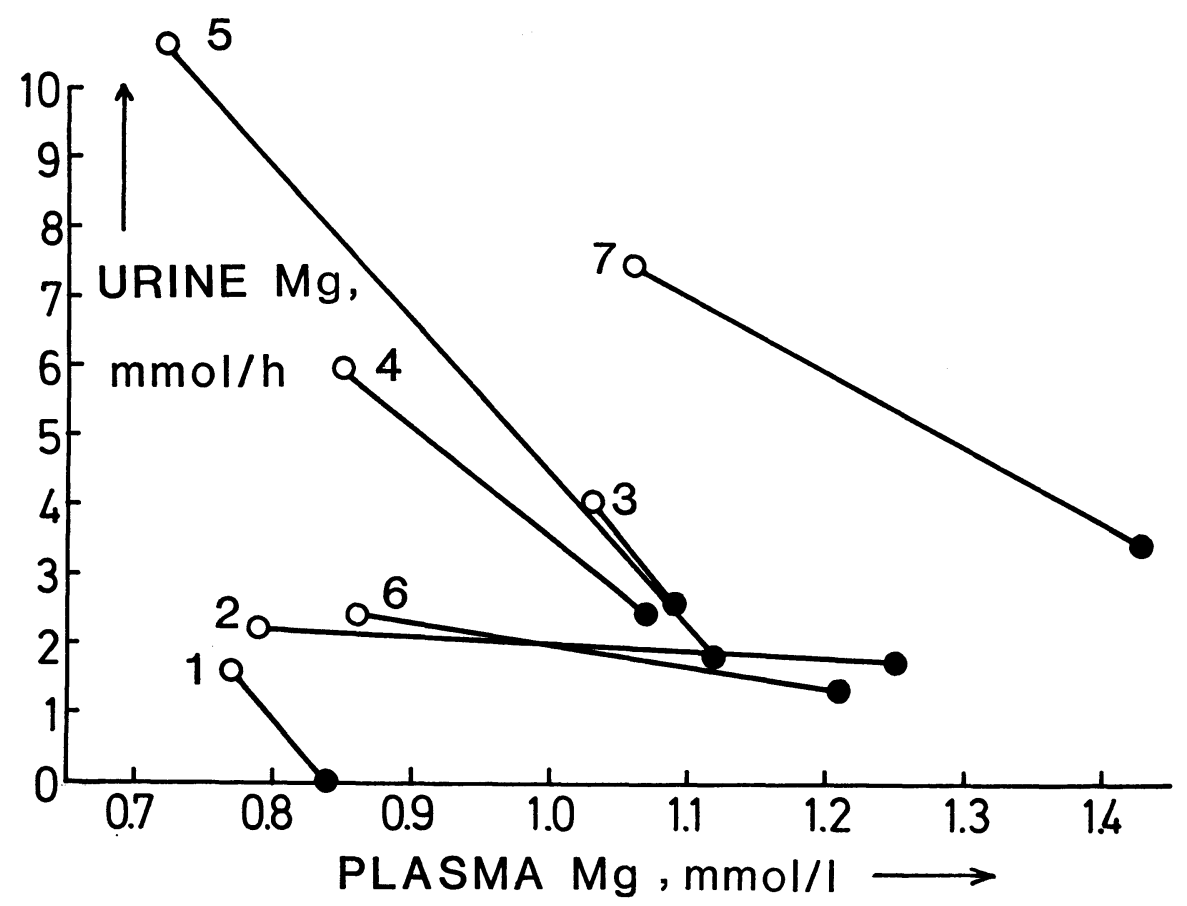

$\mathrm{F}$ i g u r e 3. Plasma concentration and urinary excretion rate for $\mathrm{Mg}$ at time points of minimum $(O)$ and subsequent maximum $(O)$ in plasma Ca after calving. Same material as in Fig. 1. Calving number denoted in the graph. No. 1 and 7 , the same animal in different years. This cow was also used in the fasting experiment (Tables 1 and 2).

T a b le 3. Apparent renal threshold for calcium at $2.3 \mathrm{mmol} / \mathrm{l}$ in blood plasma during recovery from hypocalcaemia; 7 parturitions. Same material as in Fig. 1.

\begin{tabular}{|c|c|c|c|}
\hline $\begin{array}{l}\text { Number of } \\
\text { observations }\end{array}$ & $\begin{array}{c}\text { Plasma Ca } \\
\text { mmol/l } \\
\text { range }\end{array}$ & $\begin{array}{l}\text { Urine Ca } \\
\text { mmol/h } \\
\text { mean } \pm \mathbf{s}\end{array}$ & $\begin{array}{c}\text { Urine } \mathrm{Ca} \\
\mathrm{mmol} / \mathrm{h} \\
\text { range }\end{array}$ \\
\hline $\begin{array}{r}26 \\
7\end{array}$ & $\begin{array}{l}1.6-2.19 \\
2.2-2.29\end{array}$ & $\begin{array}{l}0.033 \pm 0.004 \\
0.051 \pm 0.016\end{array}$ & $0.0025-0.12$ \\
\hline $\begin{array}{r}9 \\
40\end{array}$ & $\begin{array}{l}2.3-2.39 \\
2.4-2.68\end{array}$ & $\begin{array}{l}0.59 \pm 0.24 \\
2.6 \pm 0.42\end{array}$ & $0.11-8.95$ \\
\hline
\end{tabular}

\section{Phosphorus}

Plasma inorganic $P$ was invariably low (Fig. 1) while the parturient cows were hypocalcaemic (correlation coefficient, plasma $\mathrm{Ca}$ and $\mathrm{P}$, first 7 days post partum: $\mathrm{r}=+0.7$ ). In the 
fasting experiment plasma $P$ behaved differently. Low levels were observed after a recent decrease in plasma Ca (Tables 1 and 2). Thereafter it began to increase while the hypocalcaemia persisted (Table 1). Phosphaturia was associated with Ca recovery both after fasting and in one animal post partum (Fig. 2). Mineral regulating mechanisms may have been specially strongly activated in the phosphaturic parturient cow since she showed a faster than average return to normal Ca levels (Fig. 1). The main point for the following discussion would be the fact that $\mathrm{Mg}$ and $\mathrm{Ca}$ metabolism appeared similarly interrelated in cows with and without phosphaturia.

\section{Statistical evaluation}

In Tables 4 and 5 practically equal effects of variations in plasma $\mathrm{Ca}$ and $\mathrm{Mg}$ on urinary $\mathrm{Mg}$ excretion rate are obtained by the different correlation and variance tests performed ( $\mathbf{r}_{\text {part }}$ giving correlation between two parameters when the third parameter is maintained constant). Included in the estimates were all observations before and after parturition used in Fig. 1 ( $n=$ 100 ) and 27 sets of observations from the fasting experiment ( 8 days before to 12 days after the fast) partly reproduced in Tables 1 and 2.

Attention is drawn to the similarity between coefficients of regression obtained for the two materials (Table 4 ).

T a b l e 4. Correlation coefficients, partial ( $r_{\text {part }}$ ) and multiple (as $R^{2}$ ), and regression equations. Same materials as in Fig. 1 and Tables 1 and 2.

\begin{tabular}{llllll}
\hline & \multicolumn{2}{c}{$\begin{array}{c}\text { Calving } \\
\mathrm{n}=100)\end{array}$} & & \multicolumn{3}{c}{$\begin{array}{c}\text { Fasting } \\
(\mathrm{n}=27)\end{array}$} \\
\cline { 2 - 3 } \cline { 5 - 6 } Variables & $\mathrm{r}$ & $\mathrm{r}_{\text {part }}$ & & $\mathrm{r}$ & $\mathrm{r}_{\text {part }}$ \\
\hline $\mathrm{Mg}_{\mathrm{p}-\mathrm{Ca}_{\mathrm{p}}}$ & $-0.5^{\star \star \star}$ & $-0.6^{\star \star \star}$ & & +0.3 & -0.11 \\
$\mathrm{Mgu}_{\mathrm{u}-\mathrm{Mg}_{\mathrm{p}}}$ & $+0.22^{\star}$ & $+0.43^{\star \star \star}$ & & $+0.57^{\star \star}$ & $+0.51^{\star \star}$ \\
$\mathrm{Mg}-\mathrm{Ca}_{\mathrm{p}}$ & $+0.27^{\star \star}$ & $+0.45^{\star \star \star}$ & & $+0.65^{\star \star \star}$ & $+0.61^{\star \star}$ \\
\hline
\end{tabular}

Levels of significance

*) $\left.\left.\mathrm{P}<0.05^{\star \star}\right) \mathrm{P}<0.01{ }^{\star \star *}\right) \mathrm{P}<0.001$

Calving: $\mathrm{Mg}_{\mathrm{n}}=7.25 \times \mathrm{Mg}_{\mathrm{p}}+4.75 \times \mathrm{Ca}_{\mathrm{p}}-14.8$

$\mathbf{R}^{2}=0.24^{\star \star \star}$

Fasting: $\mathrm{Mg}_{\mathrm{u}}=6.5 \times \mathrm{Mg}_{\mathrm{p}}+5.5 \times \mathrm{Ca}_{\mathrm{p}}-15.7$

$\mathrm{R}^{2}=0.57^{\star \star \star}$

$\mathrm{Mg}_{\mathrm{u}}: \mathrm{mmol} \mathrm{Mg} / \mathrm{h}$ in urine

$\mathrm{Mg}_{\mathrm{p}}$ and $\mathrm{Ca}_{\mathrm{p}}$ : $\mathrm{mmol} / \mathrm{l}$ of $\mathrm{Mg}$ and $\mathrm{Ca}$ in plasma. 
A higher $\mathrm{R}^{2}$ value was arrived at for fasting than for parturition. However, since the parturient material was larger, equal levels of significance $(P<0.001)$ were attained. Otherwise, $R^{2}$ values well below unity would be predictable, since renal excretory rates undoubtedly are influenced by other variables in addition to plasma $\mathrm{Ca}$ and $\mathrm{Mg}$.

T a ble 5. Variance of urinary $\mathrm{Mg}$, percentages explained by variations in plasma Mg and Ca. Same materials and same symbols as in Table 4.

\begin{tabular}{lrrrrrrr}
\hline & \multicolumn{3}{c}{$\mathrm{Mg}_{\mathrm{u}}$} & & \multicolumn{2}{c}{ Partial effects of } \\
\cline { 2 - 4 } \cline { 6 - 7 } & $\mathrm{n}$ & mean & $\begin{array}{c}\text { Sum of } \\
\text { squares }\end{array}$ & & $\begin{array}{c}\mathrm{Mg}_{\mathbf{p}} \\
\%\end{array}$ & $\begin{array}{c}\mathrm{Ca}_{\mathrm{p}} \\
\%\end{array}$ \\
\hline Calving & 100 & 3.43 & 528.3 & & 10.7 & 13.8 \\
Fasting & 27 & 3.59 & 297 & & 23.3 & 34 \\
\hline
\end{tabular}

\section{Magnitude of a hypothetical tubular effect}

The tubular reabsorption rates in Table 6 were arrived at by postulating constant glomerular filtration rates $=26 \mathrm{l} / \mathrm{h}$ (Kolb 1962) and constant ultrafiltrability of plasma $\mathrm{Mg}=70 \%$ (Nordin 1976). The material was the same as in Tables 4 and 5. To be noted are the high correlation coefficients between plasma $\mathrm{Ca}$ and $\mathrm{Mg}$ reabsorption ( $\mathrm{r}=-0.7, \mathrm{Mg}$ poor urines excluded), the close correspondence between parturient and fasting values and the fact that a variation as large as about $30 \%$ in the reabsorption rate was obtained within a quite narrow Ca range, straddling the apparent renal Ca threshold (Table 3).

Deviating reabsorption rates when urinary $\mathrm{Mg}$ was $<1 \mathrm{mg} / \mathrm{h}$ (Table 6) may be explained by filtered loads below the level needed for saturation of tubular transport systems.

It should be made clear that the calculations in Table 6 provide no proof of a tubular Ca effect. A $30 \%$ decrease in glomerular filtration rate when animals become hypocalcaemic could explain equally well the Ca-related changes in $\mathrm{Mg}$ excretion. 
T a b l e 6. Theoretical renal tubular reabsorption rate for $\mathrm{Mg}\left(\mathrm{Mg}_{\mathrm{r}}\right)$ inversely related to plasma $\mathrm{Ca}\left(\mathrm{Ca}_{\mathrm{p}}\right)$. $\mathrm{Mg}_{\mathrm{r}}$ calculated as the difference between $\mathrm{Mg}$ filtered and excreted per $\mathrm{h}$. Assumed constant: GFR = $26 \mathrm{l} / \mathrm{h}$ and ultrafiltrable $\mathrm{Mg}=70 \%$ of total plasma $\mathrm{Mg}$.

\begin{tabular}{|c|c|c|c|}
\hline \multirow[b]{2}{*}{$\begin{array}{l}\text { Plasma Ca } \\
\text { mmol/l } \\
\text { range }\end{array}$} & \multicolumn{3}{|c|}{$\mathrm{Mg}_{\mathrm{r}}, \mathrm{mmol} / \mathrm{h}$, mean and standard deviation } \\
\hline & $\begin{array}{c}7 \text { calvings } \\
\text { urine } \mathrm{Mg}>1 \mathrm{mg} / \mathrm{h}\end{array}$ & $\begin{array}{l}\text { Fasting } \\
\text { urine } \mathrm{Mg} \\
>1 \mathrm{mg} / \mathrm{h}\end{array}$ & $\begin{array}{c}\text { Calving } \\
\text { and fasting } \\
\text { urine } \mathrm{Mg}<1 \mathrm{mg} / \mathrm{h}\end{array}$ \\
\hline $1.6-2.19$ & $\begin{array}{c}17.88 \pm 2.56 \\
(22)\end{array}$ & $\begin{array}{c}17.4 \pm 3.3 \\
\quad(2)\end{array}$ & $\begin{array}{c}13.95 \pm 3.47 \\
(9)\end{array}$ \\
\hline $2.2-2.39$ & $\begin{array}{c}15.06 \pm 1.91 \\
(16)\end{array}$ & $\begin{array}{c}16.3 \pm 2.84 \\
(4)\end{array}$ & $\begin{array}{c}14.54 \pm 3.23 \\
(3)\end{array}$ \\
\hline $2.4-2.59$ & $\begin{array}{c}13.75 \pm 2.11 \\
(42)\end{array}$ & $\begin{array}{c}13.54 \pm 2.23 \\
(7)\end{array}$ & \\
\hline 2.6 & $\begin{array}{c}11.09 \pm 3.74 \\
(14)\end{array}$ & $\begin{array}{c}12.30 \pm 3.32 \\
(8)\end{array}$ & \\
\hline
\end{tabular}

Number of observations in brackets.

Correlations, $\mathrm{Mg}_{\mathrm{r}}$ to $\mathrm{Ca}_{\mathrm{p}}$ :

Calving, $r=-0.62^{\star \star \star}$, within cows $r=-0.73^{\star \star \star}$

Fasting, $r=-0.31(n=27)$, Mg-poor urines excluded:

$\mathrm{r}=-0.72^{\star \star \star}(\mathrm{n}=21)$

${ }^{\star \star \star}: \mathrm{P}<0.001$

\section{DISCUSSION}

Plasma magnesium as a dependent variable

Evidently plasma $\mathrm{Mg}$ can be regarded as dependent on: 1) the excess of absorbed $\mathrm{Mg}$ which must be excreted by the kidneys to obtain a steady state condition; 2) the glomerular filtration rate; 3 ) the rate of tubular reabsorption. The plasma $\mathrm{Mg}$ level at which a given amount of $\mathrm{Mg}$ (1.) is excreted per hour must appear Ca dependent if 2 . or 3 . are influenced by plasma Ca.

Since filtration rates were not measured, only the third alternative was tested quantitatively (Table 6). The findings were consistent with the hypothesis from the literature (see introduction) of competition between the 2 elements for renal tubular reabsorption.

Magnesium at sub-threshold levels of plasma calcium

It may first be noted that the threshold level obtained for Ca for the parturient cows in Table $3(2.3 \mathrm{mmol} / \mathrm{l})$ is in good agree- 
ment with findings by Hove et al. (1983) of $2.2-2.3 \mathrm{mmol} / \mathrm{l}$. Secondly, attention is drawn to the marked variations in estimated $\mathrm{Mg}$ reabsorption (Table 6) negatively correlated to moderate changes in plasma $\mathrm{Ca}$ in the vicinity of the Ca threshold (Table 3). Possibly, when urines are practically Ca-free, Mg reabsorption is fasilitated by a sub-capacity load of Ca on a tubular carrier system common to the 2 bivalent ions. The point would be that $\mathrm{Mg}$ metabolism is influenced by Ca variations which are within a normal range.

\section{Fasting reactions}

The observations from the fasting experiment indicate that $\mathrm{Mg}$ and $\mathrm{Ca}$ metabolism are interrelated in the same manner at other stages of lactation as in newly calved cows (Tables 4-6). An important evidence of Ca effects on $\mathrm{Mg}$ is the delay in the development of fasting-induced hypomagnesaemia in Table 1. In this connection reference is made to previous measurements of fasting blood minerals in cows (Halse 1961) which show that delayed hypomagnesaemia is a regular phenomenon when blood Ca is decreased by fasting.

It is likely that the cow in Table 1 which was fasted had keto-acidosis when feeding was resumed (Halse 1958) and this may have influenced the renal handling of minerals.

\section{Hypercalcaemia}

If plasma $\mathrm{Mg}$ tends to be high during hypocalcaemia, one would expect a Mg-depressant effect associated with high Ca levels. Actually, decreases in plasma $\mathrm{Mg}$ have been observed after treatment of rats with hypercalcaemia-producing doses of vitamin D (Richardson \& Welt 1965) and in cows receiving Ca-elevating vitamin $\mathrm{D}$-metabolites (Hove et al. 1983). The first mentioned authors found no change in faecal, urinary, muscle or total carcass $\mathrm{Mg}$ in the treated animals. They did not discuss renal mechanisms and suggested that the vitamin $D$ treatment had resulted in a change in the balance between extra- and intracellular Mg. Urinary excretion rates for $\mathrm{Mg}$ of the cows studied by Hove et al. appeared unaffected by the treatment. Their material was not sufficient for the demonstration of significant effects on excretion in relation to filtered loads. 


\section{A calcium-dependent renal magnesium threshold}

Estimates based on reabsorption rates from Table 6 indicate that $\mathrm{Mg}$-poor urines can be produced at plasma $\mathrm{Mg}$ levels as high as $1 \mathrm{mmol} / \mathrm{l}$ when plasma $\mathrm{Ca}<2.2 \mathrm{mmol} / \mathrm{l}$ (tubular reabsorption $=$ filtered load). The corresponding value at Ca levels $>2.4$ would be about $0.75 \mathrm{mmol} / \mathrm{l}$ of $\mathrm{Mg}$. This last mentioned figure is in good agreement with threshold estimates from the literature (Ender et al. 1957). It also corresponds approximately to lower limits obtained for the $\mathrm{Mg}$ range of healthy cows in the field (Halse 1970). Direct measurements indicating enhancement of the $\mathrm{Mg}$ threshold during hypocalcaemia were referred to above (Results, Table 1).

\section{Calcium or hormone effects}

Seemingly convincing evidence of direct $\mathrm{Ca}$ effects on $\mathrm{Mg}$ transport was provided by Quamme's (1982) microperfusion experiments with single renal tubuli.

Additional Ca related effects on Mg metabolism mediated by Ca regulating hormones cannot be excluded. Parathormone can stimulate the tubular reabsorption of both $\mathrm{Ca}$ and $\mathrm{Mg}$ (Burnatowska et al. 1977). Tubular Mg transport may also be influenced by antidiuretic hormone, calcitonin and glucagon (Rouffignac et al. 1983). It is likely that several of the hormones mentioned become involved during the readjustment of mineral metabolism after hypocalcaemia: possibly overstimulation of mineral mobilizing mechanisms can lead to a calcitonin response. Attention is drawn to the findings during the recovery period in the fasting experiment (Tables 1 and 2). The cow became hypocalcaemic again between two periods of phosphaturia.

\section{Biological and clinical implications}

An improvement in the retention of extracellular $\mathrm{Mg}$ related to moderate decreases in plasma Ca could be of considerable homeostatic importance, delaying the development of hypomagnesaemia when the supply of minerals becomes marginal.

In the experiments referred to above (Richardson \& Welt, Hove et al.) the moderate hypomagnesaemia of hypercalcaemic animals did not lead to detectable losses of body Mg. Whether or not an abundant supply of Ca can aggravate the hypomagnesaemia on Mg-poor diets is not known. Even when the kidneys 
excrete large amounts of $\mathrm{Ca}$, the $\mathrm{Mg}$ level at which the urine becomes practically $\mathrm{Mg}$ free may be well above the tetany range.

The plasma $\mathrm{Mg}$ level of cows with milk fever can vary as widely as from about 0.4 to $1.5 \mathrm{mmol} / \mathrm{l}$ (Jonsgård 1972). The variability may reflect variations in the availability of metabolic Mg. It is suggestive that in the present study postparturient hypermagnesaemia was not observed in one animal with exceptionally low $\mathrm{Mg}$ excretion rates (Fig. 1).

The inconsistent behaviour of $\mathrm{Mg}$ in milk fever could mean that the element is of limited clinical importance in the disease. It should be noted, however, that Jonsgård found a significantly better recovery rate for milk fever patients with plasma $\mathrm{Mg}>1$ $\mathrm{mmol} / \mathrm{l}$ than for affected animals with lower $\mathrm{Mg}$ levels.

\section{ACKNOWLEDGEMENT}

This study was supported financially by the Agricultural Research Council of Norway.

\section{REFERENCES}

Alcock, N. \& I. MacIntyre: Interrelation of calcium and magnesium absorption. Clin. Sci. 1962, 22, 185-193.

Barker, E. S., J. R. Elkinton \& J. K. Clark: Studies of the renal excretion of magnesium in man. J. clin. Invest. 1959, 38, 1733-1745.

Burnatowska, M. A., C. A. Harris, R. A. L. Sutton \& J. A. Dirks: Effects of PTH and cAMP on renal handling of calcium, magnesium and phosphate in the hamster. Amer. J. Physiol. 1977, 233, 514-518.

Care, A. D. \& A. Th. van't Klooster: In vivo transport of magnesium and other cations across the wall of the gastro-intestinal tract of sheep. J. Physiol. 1965, 177, 174-191.

Dirks, J. H. \& G. A. Quamme: Renal handling of magnesium. Advanc. exp. Med. Biol. 1978, 103, 51-64.

Dishington, I. W.: Prevention of milk fever (hypocalcaemic paresis puerperalis) by dietary salt supplements. Acta vet. scand. 1975, $16,503-512$.

Ebel, H. \& T. Günther: Magnesium metabolism: A review. J. clin. Chem. clin. Biochem. 1980, 18, 257-270.

Ender, F., Inger W. Dishington, A. Helgebostad \& E. Martinsons: The magnesium problem in relation to the tetany-paresis syndrome in dairy cows. Nord. Vet.-Med. 1957, 9, 881-917.

Halse, K.: Apparent strengthening of calcium homeostasis in cows by starvation of short duration. Nord. Vet.-Med. 1958, 10, 9-16.

Halse, K.: Changes in serum calcium and magnesium in cows subjected to short periods of fasting. Proc. VIII. Intern. Grassland Congr., Reading, Berkshire, England, 1960. The Alden Press, Oxford, 1961, p. 553-558. 
Halse, $K .:$ Individual variation in blood magnesium and susceptibility to hypomagnesaemia in cows. Acta vet. scand. 1970, 11, 394414.

Hove, K., R. L. Horst \& E. T. Littledike: Effects of $1 \alpha$-Hydroxyvitamin $\mathrm{D}_{3}, 1,25$-Dihydroxyvitamin $\mathrm{D}_{2}, 1,24,25$-Trihydroxyvitamin $\mathrm{D}_{3}$, and 1,25,26-Trihydroxyvitamin $D_{3}$ on mineral metabolism and 1,25 Dihydroxyvitamin D concentrations in dairy cows. J. Dairy Sci. $1983,66,59-66$

Jonsgård, K.: A clinical study on parturient paresis in dairy cows, with special reference to factors related to recovery. Thesis. The Veterinary College of Norway, Oslo, 1972, 120 pp.

Kolb, E.: Lehrbuch der Physiologie der Haustiere. (Textbook of physiology of domestic animals). Gustav Fisher Verlag, Jena, 1962, $942 \mathrm{pp}$.

Marr, A., E. W. Moodie \& A. Robertson: Some biochemical and clinical aspects of milk fever. J. comp. Path. 1955, 65, 347-365.

Nordin, B. E. C.: Calcium, phosphate and magnesium metabolism. Clinical physiology and diagnostic procedures. Publ. Churchill Livingstone, Edinburgh-London-New York, 1976, 683 pp.

Quamme, G. A.: Effect of hypocalcaemia on renal tubular handling of calcium and magnesium. Canad. J. Physiol. Pharmacol. 1982, 60, $1275-1280$.

Richardson, J. A. \& L. G. Welt: The hypomagnesaemia of vitamin D administration. Proc. Soc. exp. Biol. Med. 1965, 118, 512-514.

Ringbom, A.: Complexation in Analytical Chemistry. Interscience Publishers, N. Y./London 1963, 395 pp.

Rouffignac, C. de, B. Corman \& N. Roinel: Stimulation by antidiuretic hormone of electrolyte tubular reabsorption in rat kidney. Amer. J. Physiol. 1983, 244, F156-164.

Samiy, A. H.E., J. L. Brown, D. L. Globus, R. H. Kessler \& D. D. Thompson: Interrelation between renal transport systems of magnesium and calcium. Amer. J. Physiol. 1960, 198, 599-602.

Sjollema, B.: Stoffwechselstörungen des Rindes. Zusammenfassender Bericht. (Metabolic disturbances of cattle. Summarizing report.). Acta vet. neerlandica 1933, Tome I — Fasc. II. 127 pp.

\section{SAMMENDRAG}

Innvirkning av kalsium på nyrekonserveringen av magnesium hos kyr.

Mengder av Ca, Mg og $\mathrm{P}$ utskilt per tidsenhet med urinen ble sammenholdt med samtidige konsentrasjoner av de 3 elementer i blodplasma fra kyr i løpet av normaliseringsperioden etter moderat hypokalsemi post partum og i et tilfelle etter fremkalling av hypokalsemi ved faste.

Nyrekonserveringen av Mg viste seg å være $\varnothing$ kt under hypokalsemi. Teoretiske tubulære reabsorpsjonshastigheter for elementet var korrelert til plasma Ca (interval ca. $2.0-2.6 \mathrm{mmol} / \mathrm{l}$ ) $\mathrm{med} \mathrm{r}=-0.7$, $\mathrm{P}<0.001$. 
Funnene kan forklare forekomsten av hypermagnesemi hos hypokalsemiske kyr og forsinkelsen i utviklingen av hypomagnesemi hos kyr med hypokalsemi etter faste.

(Received February 27, 1984).

Reprints may be requested from: K. Halse, the Department of Biochemistry, Norwegian College of Veterinary Medicine, P. O. Box 8146, Dep., 0033 Oslo 1, Norway. 